OPEN ACCESS

Edited by: Akihide Ryo,

Yokohama City University, Japan

Reviewed by:

Iwao Kukimoto,

National Institute of Infectious

Diseases, Japan

Dohun Pyeon,

University of Colorado Denver School of Medicine, United States

*Correspondence:

Girish K. Patel

patelgk@cardiff.ac.uk

Specialty section: This article was submitted to Virology,

a section of the journal

Frontiers in Microbiology

Received: 22 January 2018 Accepted: 09 March 2018

Published: 26 March 2018

Citation:

Olivero C, Lanfredini S, Borgogna C,

Gariglio M and Patel GK (2018)

HPV-Induced Field Cancerisation:

Transformation of Adult Tissue Stem

Cell Into Cancer Stem Cell.

Front. Microbiol. 9:546.

doi: 10.3389/fmicb.2018.00546

\section{HPV-Induced Field Cancerisation: Transformation of Adult Tissue Stem Cell Into Cancer Stem Cell}

\author{
Carlotta Olivero ${ }^{1,2}$, Simone Lanfredini ${ }^{2}$, Cinzia Borgogna ${ }^{1}$, Marisa Gariglio $^{1}$ and \\ Girish K. Patel ${ }^{*}$ * \\ ${ }^{1}$ Virology Unit, Department of Translational Medicine, Novara Medical School, University of Eastern Piedmont, Novara, Italy, \\ ${ }^{2}$ European Cancer Stem Cell Research Institute, Cardiff School of Biosciences, Cardiff University, Cardiff, United Kingdom
}

Field cancerisation was originally described as a basis for multiple head and neck squamous cell carcinoma (HNSCC) and is a pre-malignant phenomenon that is frequently attributable to oncogenic human papillomavirus (HPV) infection. Our work on $\beta$-HPV-induced cutaneous squamous cell carcinomas identified a novel Lrig1+ hair follicle junctional zone keratinocyte stem cell population as the basis for field cancerisation. Herein, we describe the ability for HPV to infect adult tissue stem cells in order to establish persistent infection and induce their proliferation and displacement resulting in field cancerisation. By review of the HPV literature, we reveal how this mechanism is conserved as the basis of field cancerisation across many tissues. New insights have identified the capacity for HPV early region genes to dysregulate adult tissue stem cell self-renewal pathways ensuring that the expanded population preserve its stem cell characteristics beyond the stem cell niche. HPV-infected cells acquire additional transforming mutations that can give rise to intraepithelial neoplasia (IEN), from environmental factors such as sunlight or tobacco induced mutations in skin and oral cavity, respectively. With establishment of IEN, HPV viral replication is sacrificed with loss of the episome, and the tissue is predisposed to multiple cancer stem cell-driven carcinomas.

Keywords: HPV, field cancerization, adult tissue stem cells, skin cancer stem cells, squamous cell carcinoma

\section{INTRODUCTION}

Human papillomavirus (HPV) infection is associated with oropharyngeal and anogenital cancers in both men and women. Approximately $90 \%$ of all cervical cancers are attributed to high-risk alpha-genus HPV ( $\alpha-\mathrm{HPV}$ ) infections, also $\sim 60 \%$ of squamous cell carcinomas (SCC) of the vulva, vagina, anus and penis are due to infection of $\alpha-\mathrm{HPV}$ (Crow, 2012). HPV infection is considered to be responsible for the rise in head and neck squamous cell carcinoma (HNSCC), particularly in cancers of the oropharynx and base of tongue (Marur et al., 2010; Leemans et al., 2011). Cutaneous HPVs, which are clustered in the evolutionarily distinct $\beta$-genus, have been also associated with the development of cutaneous SCC, especially in the immunosuppressed setting (Howley and Pfister, 2015; Quint et al., 2015). 
Sequential genetic and epigenetic changes occur over several years and provide the transformational basis for both intraepithelial neoplasia (IEN) and ensuing epithelial cancers (carcinoma). The proportion of transformed cells within IEN can be graded and used to define the risk of invasive disease (FIGO Committee on Gynecologic Oncology, 2014). Progression to invasive carcinoma from IEN can take many years and there is often evidence of IEN at the excised tumor margins (Mao et al., 1996; Scholes et al., 1998).

As an entity, carcinoma account for over $70 \%$ of all malignancies and over $70 \%$ of all cancer mortality (Cancer Research UK, 2017²), hence the American Association for Cancer Research Task Force on the treatment and prevention of IEN recognizes the importance of early treatment to prevent invasive disease (O'Shaughnessy et al., 2002). Intriguingly, IEN can spontaneously regress. Although more often, IEN will progress to invasive malignancies (Dakubo et al., 2007). In epithelia susceptible to HPV infection, HPV early genes can cause IEN, notably E6 and E7 expression, and is therefore a mechanistic link to cancer, as such it represents a target for cancer prevention and is therefore the basis of this review.

\section{FIELD CANCERISATION}

Field cancerization, as a concept, was coined by Slaughter et al. (1953) to explain the occurrence of multiple foci of HNSCC. In all 783 HNSCC cases studied, the authors noted IEN at the peripheral margins of the resected primary malignancy. Where the tumor depth was less than $1 \mathrm{~cm}$, they identified a second primary SCC focus in 43 of 88 cases. It is now clear that establishment of a premalignant epithelium, field cancerisation, is the basis for HNSCC, skin and cervical SCC.

Within field cancerisation, cells harbor a substantial number of mutations including those within known tumor suppressor genes, most frequently within the p53 gene (Bartkova et al., 1995; Ortiz et al., 2001; van Houten et al., 2002; Elgazzar et al., 2005; Merrick et al., 2006; Hu et al., 2012). In many tissues, the presence of mutant p53 clones is widely accepted as the hallmark of field cancerisation (Figure 1) (El-Naggar et al., 1995; Franklin et al., 1997). However, in cervical IEN, p53 is less frequently mutated (Akasofu and Oda, 1995). Within the early stage of field cancerisation there are multiple clones, but with increasing dysplasia severe field cancerisation becomes monoclonal (Figure 2) (Chung et al., 1995; Enomoto et al., 1997; Tate et al., 1997). Therefore, field cancerisation at its outset is polyclonal, implying that multiple cell lineages contribute to its occurrence as observed in active HPV infection.

Increasing mutational burden and greater dysplasia result in clonal selection, with a tendency toward mono-clonality (Figure 2). Clonal selection and expansion may result in a single clone in continuous epithelia (skin, oral and cervical tissues) or multiple clones in discontinuous epithelia (breast and lung) (Prevo et al., 1999; Simon et al., 2001; Larson et al., 2002; Tabor et al., 2002; Smeds et al., 2005). Within continuous

${ }^{1}$ http://www.cancerresearchuk.org/health-professional/cancer-statistics/ incidence/common-cancers-compared

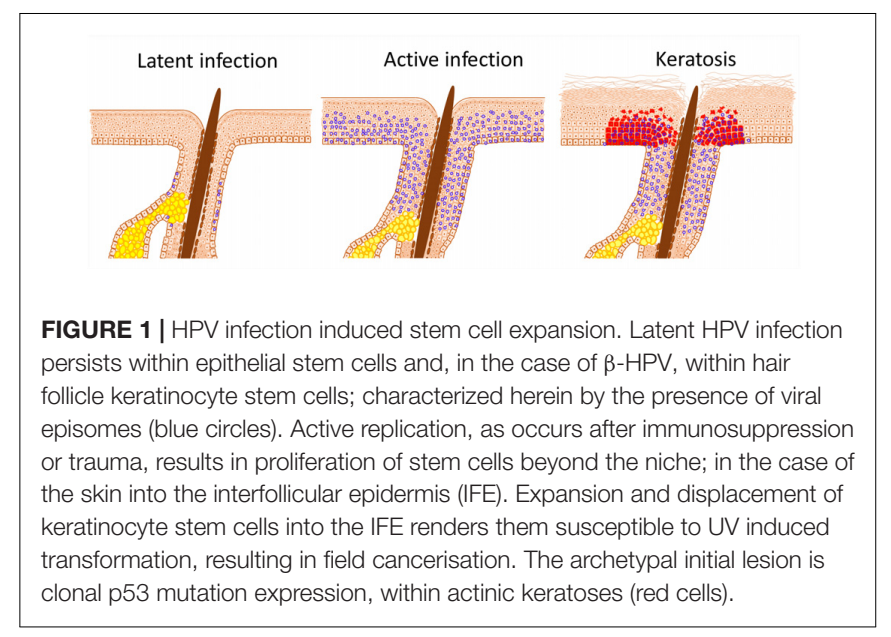

epithelia, wherein HPV infection occurs, field cancerisation and ensuing cancers exhibit common epigenetic gene silencing, chromosomal anomalies, loss of heterozygosity, single nucleotide polymorphism, mutations, changes in mitochondrial genome, and altered gene expression (transcripts and proteins) (Ha et al., 2002; Tabor et al., 2004; Shen et al., 2005; Sui et al., 2006). Hence, severe IEN (part of the field cancerisation spectrum) that gives rise to multiple cancer, has limited numbers of clones.

The ensuing SCC that arise within continuous stratified squamous epithelia are clonal with respect to the underlying field cancerisation and severe IEN (Figure 2) (Sheu et al., 1995; Kim et al., 1996; Enomoto et al., 1997; Tate et al., 1997). However, the proliferative explosion of SCC cells results in multiple evolving clones, from acquisition of new mutations, which similarly undergo Darwinian evolutionary selection (McGranahan and Swanton, 2017). As a consequence, tumors arising from within IEN are genetically distinct (Nakashima et al., 1995; Shinmura et al., 1998). Hence, Darwinian evolutionary clonal selection determines the loss of clones in field cancerisation and determines the size of multiple clones within the emerging SCC.

\section{HPV INFECTION AND STEM CELL EXPANSION}

Human papillomavirus (HPV) binds epithelial cell heparan sulfate proteoglycans and cell specific receptors to gain entry by both clathrin-dependent and -independent endocytosis (McMillan et al., 1999; Day et al., 2003; Shafti-Keramat et al., 2003; Spoden et al., 2008; Schelhaas et al., 2012; Day and Schelhaas, 2014). Infection leads to the establishment of the HPV circular double-stranded genome as a stable episome within some cells of the basal layer (Dell et al., 2003). In the case of alpha-HPV, the viral genome can integrate into the host genome, whereas for beta-HPV, the viral genome remains episomal (Quint et al., 2015). Viral replication proteins E1 and E2 are required for the maintenance of the viral genome in the basal layer (Frattini et al., 1996; Stubenrauch et al., 1998; McBride, 2013). HPV infection of epithelial basal cells may be non-selective and by chance may involve adult tissue stem cells that reside in this layer. 


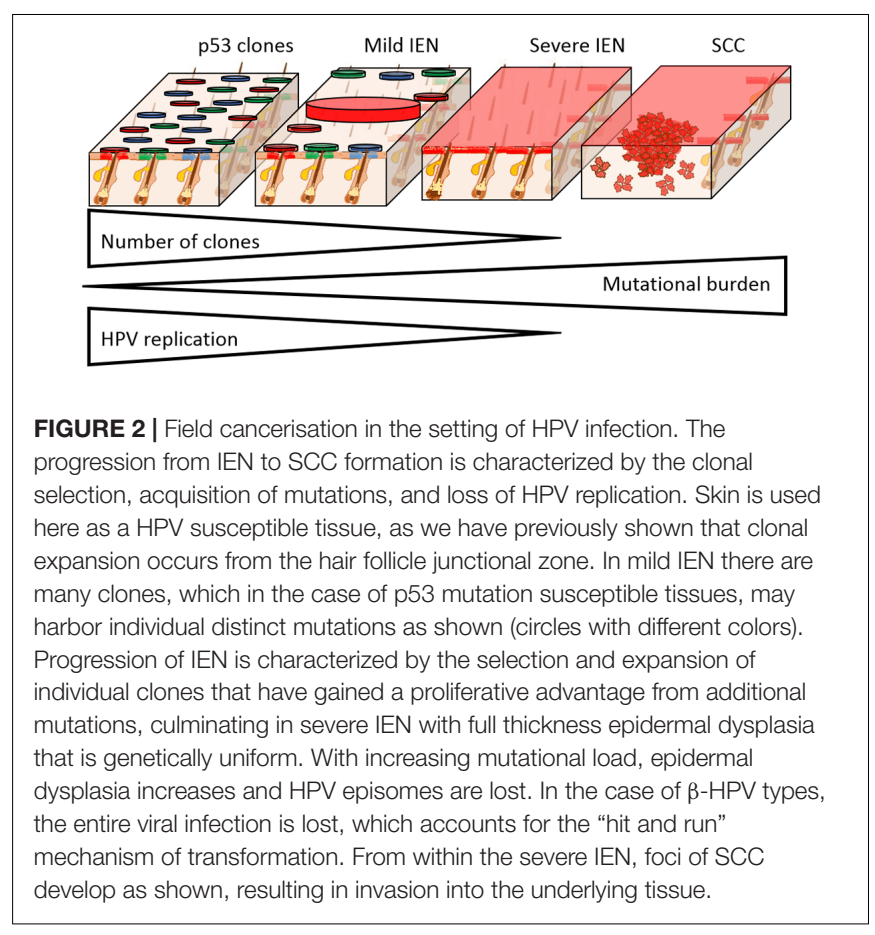

Most HPV infections are spontaneously cleared. For example, the risk of $\alpha-\mathrm{HPV}$ female genital infection over a lifetime is up to $80 \%$ (Syrjanen et al., 1990), but within 1-2 years most individuals clear the virus (Rodríguez et al., 2008). Although HPV may not specifically bind epithelial adult tissue stem cells for infection, as discussed earlier, persistent and or latent infection is presumed to involve epithelial adult tissue stem cells, but has not been determined for all tissues as stem cell markers are lacking (Schmitt et al., 1996; Boxman et al., 1997; Maglennon et al., 2011; Kranjec and Doorbar, 2016). Notably, the proposed reservoir for latent $\beta$-HPV infection has been the hair follicles (Boxman et al., 1997; De Koning et al., 2007; Galloway and Laimins, 2015; Quint et al., 2015; Hufbauer and Akgül, 2017; Tommasino, 2017). Animal models substantiated these clinical findings and moreover showed that the sub-populations of infected hair follicle cells have increased clonogenic potential, a hallmark of adult tissue stem cells (Schmitt et al., 1996; Lanfredini et al., 2017). In the oncogenic $\beta$-HPV8 transgenic mouse model we observed skin thickening (acanthosis), which was evident from birth and attributable to an expansion of the Lrig1 hair follicle adult tissue stem population (Lanfredini et al., 2017). In the absence of overt cutaneous lesions, such as papilloma or carcinoma, both unsorted and Lrig1+ keratinocytes demonstrated increased colony forming efficiency (increased clonogenicity) consistent with an expansion in keratinocyte stem cell numbers. Similarly, earlier studies on the cottontail rabbit model of HPV infection had also demonstrated the hair follicle to be the site of persistent HPV infection and, through similar colony forming assays, an expansion of the hair follicle junctional zone keratinocyte stem cells was reported (Schmitt et al., 1996). In these two studies, papilloma arose as a result of continued keratinocyte stem cell expansion into the adjacent overlying epidermis. For example, human benign cutaneous viral warts similarly result from keratinocyte stem cells expansion (Egawa, 2003). It is possible that the immune privilege provided by the stem cells niche prevents immune attack, thereby facilitating long term infection.

\section{HPV-INDUCED EPIDERMAL PROLIFERATION}

In cervical lesions caused by the $\alpha$-HPVs, the viral oncogenes E6 and E7 increase proliferation of suprabasal epithelial cells. Along with E1 and E2, viral replication requires E6 and E7 for entry into S-phase. Upon leaving the basal layer, keratinocytes enter into a program of terminal differentiation in order to produce a protective barrier. However, in HPV infection, suprabasal cells continue to proliferate and are prevented from entering terminal differentiation (Sherman et al., 1997; Doorbar, 2006). Oncogenic viruses, including HPV, deregulate cell growth by disruption of $\mathrm{pRb}$ (retinoblastoma protein) binding to the E2F family of transcription factors though E7 binding pRb. Host p21 and p27 cyclin-dependent kinase inhibitors moderate the ability of E7 to drive cell proliferation in some cells (Doorbar, 2006; Tomaić, 2016). Inactive complexes with E7 and cyclin E occur within differentiating keratinocytes that express high levels of p21 and p27 (Noya et al., 2001; Akgül et al., 2006). In synchrony, highrisk $\alpha-\mathrm{HPV}$ E6 prevent growth arrest or apoptosis by binding to $\mathrm{p} 53$, thus leading to p53 ubiquitination and degradation. In benign infections, proliferating cells remain in the epithelial basal layer, including within the hair follicle. As the infected cell enters the suprabasal cell layers of the epidermis, virus production is switched on resulting in viron assembly (Peh et al., 2002).

\section{HPV INFECTION INDUCES STEM CELL EXPANSION AND SELF-RENEWAL PATHWAYS}

Fluorescent labeling studies in mice using lineage tracing have concluded that stem cell division is prominently ( $90 \%)$ asymmetric; in which there is renewal of the stem cell and a daughter cell that is committed to terminal differentiation (Clayton et al., 2007; Doupé et al., 2012). Stochastic cell division in basal cells, including stem cells, can lead to HPV infection clearance. Mathematical modeling together with epidemiological data suggests that natural stem cell dynamics contributes $>80 \%$ toward viral clearance rather than rejection by the immune system (Ryser et al., 2015). Thus, factors that promote adult tissue stem cell symmetrical cell division resulting in an increase in stem cell numbers may perpetuate infection accounting for the correlation between the increased risk of persistent infections associated cervical cancer and long-term use of combined oral contraceptives (Muñoz et al., 2006). This may also explain the basis for why trauma, ultraviolet light and repetitive exposure to the virus are essential in maintaining site-specific HPV infection (Kranjec and Doorbar, 2016). 
Adult tissue stem cell expansion, as proposed for the mechanism of HPV-induced field cancerisation, is dependent on symmetrical division of existing stem cells. As discussed, HPV viral oncogenes will drive proliferation of infected adult tissue stem cells by targeting p53 or pRb. Importantly, the binding of $\mathrm{E} 7$ to $\mathrm{pRb}$ releases repression of both sex determining region Y-box 2 (Sox2) and octamer-binding transcription factor 4 (Oct4) (Kareta et al., 2015). Similarly, $\alpha$-HPV E6 mediated degradation of p53 results increased Nanog expression, which is normally transcriptionally repressed by p53 (Lin et al., 2005). Thus, HPV early region genes promote self-renewal pathways.

In addition, high-risk $\alpha$-HPV E7 induces expression of the key transcription factor Oct 4 and also directly to enhance activation of its target genes (Brehm et al., 1997, 1999; Organista-Nava et al., 2016). Another key transcription factor, Kruppel-like factor 4 (Klf4), is also upregulated and hypoSUMOylated by high risk $\alpha$-HPV E6 (Gunasekharan et al., 2016). Simultaneously, $\beta$-HPV E6 blocks differentiation by inhibition of $\mathrm{C} / \mathrm{EBP} \alpha$, Notch signaling and Hes1 upregulation (Tyagi et al., 2016; Kranjec et al., 2017; Marthaler et al., 2017; Meyers et al., 2017). $\beta$-HPV E6 specifically binds to a cellular target MAML1, resulting in the inhibition of Notch-mediated transcription, which is important to keep infected keratinocytes in a proliferative state (Meyers et al., 2017). $\alpha$-HPV E7 also prevents histone3 Lysine27 (H3K27) trimethylation and therefore maintains adult tissue stem cells in a permissive epigenetic state (McLaughlin-Drubin et al., 2011). Thus, HPV causes proliferation of adult tissue stem cells and maintains stemness of these cells as they egress from the stem cell niche, consistent with expression of stem cell proteins and observations in vitro of increased colony forming efficiency (Hufbauer et al., 2013; Lindquist et al., 2014).

\section{TRANSITION FROM HPV-INDUCED STEM CELL EXPANSION TO IEN}

The earliest evolution of HPV-induced stem cell expansion into visible lesions is the presence of dysregulated stratification within the epidermis, resulting in benign keratoses (the archetypal lesion in epidermodysplasia verruciformis) or cutaneous warts. Similarly, mucosal HPV lesions include condyloma or leukoplakia within the genitalia and oral mucosa (Cubie, 2013). In addition, persistent infections with high-risk HPV types simultaneously trigger neoplastic change (Rodríguez et al., 2010).

The transition from benign to premalignant lesion has been characterized by TP53 immunostaining, resulting from mutation acquisition, and manifesting as a small micro-clonal expansion comprising of 60-3000 cells presenting clinically as an actinic (solar) keratosis or leukoplakia (Jonasson et al., 1996; Ren et al., 1966; Ponten et al., 1997; Waridel et al., 1997; Garcia et al., 1999; van Houten et al., 2002). In the skin, these p53 microclonal patches were larger and more frequent in sun-exposed than sun-shielded areas, suggesting that mutations arise from $\mathrm{UV}$. In addition, HPV is able to inhibit DNA repair through E6 protein expression, facilitating acquisition of p53 mutations (Wallace et al., 2012; Hufbauer et al., 2015; McKinney et al., 2015). Gain-of-function p53 mutation acquisition results in persistence of the protein within cells to promote transformation (Caulin et al., 2007).

Progression of field cancerisation toward severe IEN is associated with loss of the viral episome. In HPV infection, such as benign warts, epithelial proliferating cells remain in the basal layers, with genome amplification and virion assembly occurring within the suprabasal cell layers (Peh et al., 2002; Middleton et al., 2003). In the case of the high-risk HPV types the relative thickness of the basal layers is increased, presumably due to expansion in the number of adult tissue stem cells. Progression to IEN is characterized by a loss of terminal differentiation and therefore the expression of viral coat proteins is retarded (Figure 2) (Middleton et al., 2003). For example in cervical IEN, increasing dysplasia is associated with reduced virion production and loss of viral episomes. This phenomenon is even more evident in the case of skin infection by $\beta$-HPV types, which do not integrate into the host genome, and do not maintain viral DNA in the late stages of skin cancer progression. For example, SCC that develop within HPV associated Organ Transplant Recipient (OTR) field cancerisation no longer express $\beta$-HPV proteins (Borgogna et al., 2014) Similarly, HPV expression was lost during actinic keratosis transformation to SCC in a nude mouse xenograft model (Borgogna et al., 2018). Hence, the progression to cancer from IEN occurs independent of virus production, and for the beta genotypes in the skin, this is referred to as the "hit and run" mechanism of carcinogenesis (Howley and Pfister, 2015; Quint et al., 2015).

Field cancerisation emerging from HPV induced amplification of adult tissue stem cells results from additional environmental induced mutations. The area of IEN can be large, in the oral cavity it can be over $7 \mathrm{~cm}$ in diameter and is predisposed to multiple primary HNSCC and therefore poor prognosis (Tabor et al., 2002, 2004; Baxi et al., 2014). Intriguingly, HPV associated HNSCC demonstrate a favorable response to chemotherapy (Hayes et al., 2015; Vokes et al., 2015). Likewise, HPV and non-HPV vulvar SCC have distinct mutational profiles and moreover multiple primaries developing from within HPV IEN demonstrate separate clonal basis (Rosenthal et al., 2002; Hampl et al., 2007). Hence, HPV-induced adult tissue stem cell expansion risks the generation of IEN that in turn is predisposed to further transformation resulting in multiple primary tumors.

\section{HPV INFECTION DRIVEN CANCER STEM CELLS}

Many cancers exhibit hierarchical growth with evidence of differentiation consistent with the cancer stem cell model (Colmont et al., 2012). Wherein a subset of cancer cells, called "cancer stem cells", which continue to exhibit stem cell characteristic, serve to promote tumor growth through selfrenewal with symmetric and asymmetric cell division (Patel et al., 2012; Colmont et al., 2013). There is evidence of active self-renewal in HPV-induced female genital tract cancers, cervical and vulval cancers, which characteristically express the stem cell transcription factors Sox 2, Oct4, and Hes1 
(Brustmann and Brunner, 2013; Kim et al., 2015; Napoletano et al., 2016; Gut et al., 2018). In cervical cancer, HPV gene E6 can enhance self-renewal associated hedgehog transcription factor Gli1 expression and therefore increase cancer stem cell numbers (Vishnoi et al., 2016).

Head and neck squamous cell carcinoma (HNSCC) identification and characterisation of cancer stem cells has been supported by in vitro and in vivo assays (Prince et al., 2007). Similar to HPV-induced female genital tract cancers, the self-renewal associated transcription factor Sox 2 was found expressed in HPV associated HNSCC, resulting from HPV E6/7 associated PI3K-AKT pathway activation (Keysar et al., 2016; Xi et al., 2016). The ensuing HPV-associated HNSCC retain cancer stem cell markers, CD44, CD24, ALHD1, and functional side population characteristics (Tang et al., 2013; Lindquist et al., 2014; Pullos et al., 2015). Overall, HPV associated HNSCC has favorable outcome compared to non-HPV associated HNSCC, and intriguingly this has been attributed to reduced cancer stem cell frequency in HPV HNSCC (Rietbergen et al., 2014; Vlashi et al., 2016). High numbers of cancer stem cells in HNSCC, irrespective of HPV status, is associated with poor outcome and lack of response to both radiotherapy and chemotherapy (Linge et al., 2016; Modur et al., 2016). Hence, the role of HPV to cause both normal stem cell and cancer stem cell expansion, may establish the basis for cancer stem cell driven tumor growth and influence cancer outcome.

\section{CONCLUSION}

This review has focused on HPV infection, notably oncogenic genotypes from both the alpha and beta genus. Within the tropic tissue that was breached to allow viral entry, persistent infection requires that resident adult tissue stem cells are infected. HPVinfected adult tissue stem cells, similar to other HPV-infected

\section{REFERENCES}

Akasofu, M., and Oda, Y. (1995). Immunohistochemical detection of p53 in cervical epithelial lesions with or without infection of human papillomavirus types 16 and 18. Virchows Arch. 425, 593-602. doi: 10.1007/BF00199349

Akgül, B., Cooke, J. C., and Storey, A. (2006). HPV-associated skin disease. J. Pathol. 208, 165-175. doi: 10.1002/path.1893

Bartkova, J., Lukas, J., Müller, H., Strauss, M., Gusterson, B., and Bartek, J. (1995). Abnormal patterns of D-type cyclin expression and G1 regulation in human head and neck cancer. Cancer Res. 55, 949-956.

Baxi, S. S., Pinheiro, L. C., Patil, S. M., Pfister, D. G., Oeffinger, K. C., and Elkin, E. B. (2014). Causes of death in long-term survivors of head and neck cancer. Cancer 120, 1507-1513. doi: 10.1002/cncr.28588

Borgogna, C., Lanfredini, S., Peretti, A., De Andrea, M., Zavattaro, E., Colombo, E., et al. (2014). Improved detection reveals $\beta$-papillomavirus infection in skin lesions from kidney transplant recipients. Mod. Pathol. 27, 1101-1115. doi: 10.1038/modpathol.2013.240

Borgogna, C., Olivero, C., Lanfredini, S., Calati, F., De Andrea, M., Zavattaro, E., et al. (2018). $\beta$-HPV infection correlates with early stages of carcinogenesis in skin tumors and patient-derived xenografts from a single center kidney transplant recipient cohort. Front. Microbiol. 9:117. doi: 10.3389/fmicb.2018. 00117

Boxman, I. L., Berkhout, R. J., Mulder, L. H., Wolkers, M. C., Bouwes Bavinck, J. N., Vermeer, B. J., et al. (1997). Detection of human papillomavirus DNA cells are forced to proliferate, leading to their expansion as adult tissue stem cells beyond their native niche. This expansion renders them susceptible to environmental carcinogens. In the case of skin, $\beta$-HPV genotypes induce hair follicle junctional zone keratinocyte stem cells to proliferate and expand into the overlying epidermis, whereupon they are susceptible to UVinduced mutations. Transformational mutations result in field cancerisation, with additional driver mutations, causing clonal selection as IEN progresses from mild to severe. Additional mutations then can give rise to multiple cancers. Hence, HPVinduced stem cell expansion predisposes to and, through viral oncogene expression, induces the generation of cancer stem cells, which in turn can define the fate of tumor and patient prognosis. Hence, we propose that the ability of oncogenic HPV infection to manipulate adult tissue stem cells underpin its ability to drive cancer growth through promotion of cancer stem cells.

\section{AUTHOR CONTRIBUTIONS}

$\mathrm{CO}, \mathrm{SL}$, and GP conceived the idea. CO, SL, CB, MG, and GP drafted the manuscript with inputs from all authors. All authors have made final approval for the final version to be submitted.

\section{FUNDING}

GP was supported by British Skin Foundation (003/SG/17), Leo Foundation (LF17070), and Hywel Dda University Health Board. $\mathrm{CO}$ was funded by FCRT and Fondazione Goria-Bando Talenti della Società Civile 2016. MG was supported by Associazione Italiana per la Ricerca sul Cancro - AIRC grant IG2016. CB was supported by Compagnia di San Paolo (CSP2014) and the Italian Ministry for University and Research - MIUR (PRIN 2015).

in plucked hairs from renal transplant recipients and healthy volunteers. J. Investig. Dermatol. 108, 712-715. doi: 10.1111/1523-1747.ep12292090

Brehm, A., Ohbo, K., and Scholer, H. (1997). The carboxy-terminal transactivation domain of Oct-4 acquires cell specificity through the POU domain. Mol. Cell. Biol. 17, 154-162. doi: 10.1128/MCB.17.1.154

Brehm, A., Ohbo, K., Zwerschke, W., Botquin, V., Jansen-Durr, P., and Scholer, H. R. (1999). Synergism with germ line transcription factor Oct-4: viral oncoproteins share the ability to mimic a stem cell-specific activity. Mol. Cell. Biol. 19, 2635-2643. doi: 10.1128/MCB.19.4.2635

Brustmann, H., and Brunner, A. (2013). Immunohistochemical expression of SOX2 in vulvar intraepithelial neoplasia and squamous cell carcinoma. Int. J. Gynecol. Pathol. 32, 323-328. doi: 10.1097/PGP.0b013e31825d820e

Caulin, C., Nguyen, T., Lang, G. A., Goepfert, T. M., Brinkley, B. R., Cai, W. W., et al. (2007). An inducible mouse model for skin cancer reveals distinct roles for gain- and loss-of-function p53 mutations. J. Clin. Invest. 117, 1893-1901. doi: $10.1172 /$ JCI31721

Chung, G. T., Sunderasan, V., Hasleton, P., Rudd, R., Taylor, R., and Rabbitts, P. (1995). Sequential molecular changes in lung cancer development. Oncogene 11, 2591-2598.

Clayton, E., Doupé, D., Klein, A., Winton, D., Simons, B., and Jones, P. H. (2007). A single type of progenitor cell maintains normal epidermis. Nature 446, 185-189. doi: 10.1038/nature05574

Colmont, C. S., Benketah, A., Reed, S. H., Hawk, N. V., Telford, W. G., Ohyama, M., et al. (2013). CD200-expressing human basal cell carcinoma cells initiate 
tumor growth. Proc. Natl. Acad. Sci. U.S.A. 110, 1434-1439. doi: 10.1073/pnas. 1211655110

Colmont, C. S., Harding, K. G., Piguet, V., and Patel, G. K. (2012). Human skin cancer stem cells: a tale of mice and men. Exp. Dermatol. 21, 576-580. doi: $10.1111 /$ j.1600-0625.2012.01533.x

Crow, J. M. (2012). HPV: the global burden. Nature 488, S2-S3. doi: 10.1038/ 488S2a

Cubie, H. A. (2013). Diseases associated with human papillomavirus infection. Virology 445, 21-34. doi: 10.1016/j.virol.2013.06.007

Dakubo, G., Jakupciak, J., Birch-Machin, M., and Parr, R. L. (2007). Clinical implications and utility of field cancerization. Cancer Cell Int. 7:2. doi: 10.1186/ 1475-2867-7-2

Day, P. M., Lowy, D. R., and Schiller, J. T. (2003). Papillomaviruses infect cells via a clathrin-dependent pathway. Virology 307, 1-11. doi: 10.1016/S0042-6822(02) 00143-5

Day, P. M., and Schelhaas, M. (2014). Concepts of papillomavirus entry into host cells. Curr. Opin. Virol. 4, 24-31. doi: 10.1016/j.coviro.2013.11.002

De Koning, M. N., Struijk, L., Bavinck, J. N., Kleter, B., Ter Schegget, J., and Quint, W. G. (2007). Betapapillomaviruses frequently persist in the skin of healthy individuals. J. Gen. Virol. 88, 1489-1495. doi: 10.1099/vir.0.82 732-0

Dell, G., Wilkinson, K. W., Tranter, R., Parish, J., Leo Brady, R., and Gaston, K. (2003). Comparison of the structure and DNA-binding properties of the E2 proteins from an oncogenic and a non-oncogenic human papillomavirus. J. Mol. Biol. 334, 979-991. doi: 10.1016/j.jmb.2003.10.009

Doorbar, J. (2006). Molecular biology of human papillomavirus infection and cervical cancer. Clin. Sci. 110, 525-541. doi: 10.1042/CS2005 0369

Doupé, D. P., Alcolea, M. P., Roshan, A., Zhang, G., Klein, A. M., Simons, B. D., et al. (2012). A single progenitor population switches behavior to maintain and repair esophageal epithelium. Science 337, 1091-1093. doi: 10.1126/science. 1218835

Egawa, K. (2003). Do human papillomaviruses target epidermal stem cells? Dermatology 207, 251-254. doi: 10.1159/000073085

Elgazzar, R. F., Ali, A., Eldreeny, E., and Moustafa, K. (2005). Over expression of P53 and P21 in normal oral mucosa adjacent to resected squamous cell carcinomas may be an evidence of field cancerization. Int. J. Cancer Prev. 2, 1-8.

El-Naggar, A. K., Lai, S., Luna, M. A., Zhou, X. D., Weber, R. S., Goepfert, H., et al. (1995). Sequential p53 mutation analysis of the preinvasive and invasive head and squamous carcinoma. Int. J. Cancer 64, 196-201. doi: 10.1002/ijc. 2910640309

Enomoto, T., Haba, T., Fujita, M., Hamada, T., Yoshino, K., Nakashima, R., et al. (1997). Clonal analysis of high-grade squamous intraepithelial lesions of the uterine cervix. Int. J. Cancer 73, 339-344. doi: 10.1002/(SICI)10970215(19971104)73:3<339::AID-IJC6>3.0.CO;2-0

FIGO Committee on Gynecologic Oncology (2014). FIGO staging for carcinoma of the vulva, cervix, and corpus uteri. Int. J. Gynaecol. Obstet. 125, 97-98. doi: 10.1016/j.ijgo.2014.02.003

Franklin, W. A., Gazdar, A. F., Haney, J., Wistuba, I. I., La Rosa, F. G., Kennedy, T., et al. (1997). Widely dispersed p53 mutation in respiratory epithelium. A novel mechanism for field carcinogenesis. J. Clin. Invest. 100, 2133-2137. doi: 10.1172/JCI119748

Frattini, M. G., Lim, H. B., and Laimins, L. A. (1996). In-vitro synthesis of oncogenic human papillomaviruses requires episomal genomes for differentiation-dependent late gene expression. Proc. Natl. Acad. Sci. U.S.A. 93, 3062-3067. doi: 10.1073/pnas.93.7.3062

Galloway, D. A., and Laimins, L. A. (2015). Human papillomaviruses: shared and distinct pathways for pathogenesis. Curr. Opin. Virol. 14, 87-92. doi: 10.1016/j. coviro.2015.09.001

Garcia, S. B., Park, H. S., Novelli, M., and Wright, N. A. (1999). Field cancerization, clonality, and epithelial stem cells: the spread of mutated clones in epithelial sheets. J. Pathol. 187, 61-81. doi: 10.1002/(SICI)1096-9896(199901)187:1<61:: AID-PATH247>3.0.CO;2-I

Gunasekharan, V. K., Li, Y., Andrade, J., and Laimins, L. A. (2016). Posttranscriptional regulation of Klf4 by high-risk human papillomaviruses is necessary for the differentiation-dependent viral life cycle. PLoS Pathog. 12:e1005747. doi: 10.1371/journal.ppat.1005747
Gut, A., Moch, H., and Choschzick, M. (2018). SOX2 gene amplification and overexpression is linked to HPV-positive Vulvar Carcinomas. Int. J. Gynecol. Pathol. 37, 68-73. doi: 10.1097/PGP.0000000000000388

Ha, P. K., Tong, B. C., Westra, W. H., Sanchez-Cespedes, M., Parrella, P., and Zahurak, M. (2002). Mitochondrial C-tract alteration in premalignant lesions of the head and neck: a marker for progression and clonal proliferation. Clin. Cancer Res. 8, 2260-2265.

Hampl, M., Wentzensen, N., Vinokurova, S., von Knebel-Doeberitz, M., Poremba, C., Bender, H. G., et al. (2007). Comprehensive analysis of 130 multicentric intraepithelial female lower genital tract lesions by HPV typing and p16 expression profile. J. Cancer Res. Clin. Oncol. 133, 235-245. doi: 10. 1007/s00432-006-0162-0

Hayes, D. N., Van Waes, C., and Seiwert, T. Y. (2015). Genetic landscape of human papillomavirus-associated head and neck cancer and comparison to tobacco-related tumors. J. Clin. Oncol. 33, 3227-3234. doi: 10.1200/JCO.2015. 62.1086

Howley, P. M., and Pfister, H. J. (2015). Beta genus papillomaviruses and skin cancer. Virology 479-480, 290-296. doi: 10.1016/j.virol.2015.02.004

Hu, B., Castillo, E., Harewood, L., Ostano, P., Reymond, A., Dummer, R., et al. (2012). Multifocal epithelial tumors and field cancerization from loss of mesenchymal CSL signaling. Cell 149, 1207-1220. doi: 10.1016/j.cell.2012.0 3.048

Hufbauer, M., and Akgül, B. (2017). Molecular mechanisms of human papillomavirus induced skin carcinogenesis. Viruses 9:E187. doi: 10.3390/ v9070187

Hufbauer, M., Biddle, A., Borgogna, C., Gariglio, M., Doorbar, J., Storey, A., et al. (2013). Expression of $\beta$-papillomavirus oncogenes increases the number of keratinocytes with stem cell-like properties. J. Virol. 87, 12158-12165. doi: 10.1128/JVI.01510-13

Hufbauer, M., Cooke, J., van der Horst, G. T., Pfister, H., Storey, A., and Akgül, B. (2015). Human papillomavirus mediated inhibition of DNA damage sensing and repair drives skin carcinogenesis. Mol. Cancer. 14:183. doi: 10.1186/s12943015-0453-7

Jonasson, A. S., Kunala, S., Price, G. J., Restifo, R. J., Spinelli, H. M., Persing, J. A., et al. (1996). Frequent clones of p53-mutated keratinocytes in normal skin. Proc. Natl. Acad. Sci. U.S.A. 93, 14025-14029. doi: 10.1073/pnas.93.24.1 4025

Kareta, M. S., Gorges, L. L., Hafeez, S., Benayoun, B. A., Marro, S., Zmoos, A. F., et al. (2015). Inhibition of pluripotency networks by the Rb tumor suppressor restricts reprogramming and tumorigenesis. Cell Stem Cell 16, 39-50. doi: 10.1016/j.stem.2014.10.019

Keysar, S. B., Le, P. N., Miller, B., Jackson, B. C., Eagles, J. R., Nieto, C., et al. (2016). Regulation of head and neck squamous cancer stem cells by PI3K and SOX2. J. Natl. Cancer Inst 109:djw189. doi: 10.1093/jnci/djw189

Kim, B. W., Cho, H., Choi, C. H., Ylaya, K., Chung, J. Y., Kim, J. H., et al. (2015). Clinical significance of Oct4 and Sox 2 protein expression in cervical cancer. BMC Cancer 15:1015. doi: 10.1186/s12885-015-2015-1

Kim, Y. T., Thomas, N. F., Kessis, T. D., Wilkinson, E. J., Hedrick, L., and Cho, K. R. (1996). p53 mutations and clonality in vulvar carcinoma and squamous hyperplasias; evidence suggesting that squamous hyperplasias do not serve as direct precursors of human papillomavirus-negative vulvar carcinomas. Hum. Pathol. 27, 389-395. doi: 10.1016/S0046-8177(96)90113-6

Kranjec, C., and Doorbar, J. (2016). Human papillomavirus infection and induction of neoplasia: a matter of fitness. Curr. Opin. Virol. 20, 129-136. doi: 10.1016/j. coviro.2016.08.011

Kranjec, C., Holleywood, C., Libert, D., Griffin, H., Mahmood, R., Isaacson, E., et al. (2017). Modulation of basal cell fate during productive and transforming HPV16 infection is mediated by progressive E6-driven depletion of Notch. J. Pathol. 242, 448-462. doi: 10.1002/path.4917

Lanfredini, S., Olivero, C., Borgogna, C., Calati, F., Powell, K., Davies, K. J., et al. (2017). HPV8 field cancerization in a transgenic mouse model is due to Lrig1+ keratinocyte stem cell expansion. J. Invest. Dermatol. 137, 2208-2216. doi: 10.1016/j.jid.2017.04.039

Larson, P. S., de las Morenas, A., Bennett, S. R., Cupples, L. A., and Rosenberg, C. L. (2002). Loss of heterozygosity or allele imbalance in histologically normal breast epithelium is distinct from loss of heterozygosity or allele imbalance in coexisting carcinomas. Am. J. Pathol. 161, 283-290. doi: 10.1016/S0002-9440(10) 64180-6 
Leemans, C. R., Braakhuis, B. J., and Brakenhoff, R. H. (2011). The molecular biology of head and neck cancer. Nat. Rev. Cancer 11, 9-22. doi: 10.1038/ nrc2982

Lin, T., Chao, C., Saito, S., Mazur, S. J., Murphy, M. E., Appella, E., et al. (2005). p53 induces differentiation of mouse embryonic stem cells by suppressing nanog expression. Nat. Cell. Biol. 7, 165-171. doi: 10.1038/ncb1211

Lindquist, D., Näsman, A., Tarján, M., Henriksson, R., Tot, T., Dalianis, T., et al. (2014). Expression of LRIG1 is associated with good prognosis and human papillomavirus status in oropharyngeal cancer. Br. J. Cancer 110, 1793-1800. doi: $10.1038 /$ bjc. 2014.87

Linge, A., Lohaus, F., Löck, S., Nowak, A., Gudziol, V., Valentini, C., et al. (2016). HPV status, cancer stem cell marker expression, hypoxia gene signatures and tumour volume identify good prognosis subgroups in patients with HNSCC after primary radiochemotherapy: a multicentre retrospective study of the German Cancer Consortium Radiation Oncology Group (DKTK-ROG). Radiother. Oncol. 121, 364-373. doi: 10.1016/j.radonc.2016.11.008

Maglennon, G. A., McIntosh, P., and Doorbar, J. (2011). Persistence of viral DNA in the epithelial basal layer suggests a model for papillomavirus latency following immune regression. Virology 414, 153-163. doi: 10.1016/j.virol.2011.03.019

Mao, L., Lee, J. S., Fan, Y. H., Ro, J. Y., Batsakis, J. G., Lippman, S., et al. (1996). Frequent microsatellite alterations at chromosomes 9 p21 and 3 p14 in oral premalignant lesions and their value in cancer risk assessment. Nat. Med. 2, 682-685. doi: 10.1038/nm0696-682

Marthaler, A. M., Podgorska, M., Feld, P., Fingerle, A., Knerr-Rupp, K., Grässer, F., et al. (2017). Identification of $\mathrm{C} / \mathrm{EBP} \alpha$ as a novel target of the HPV8 E6 protein regulating miR-203 in human keratinocytes. PLoS Pathog. 13:e1006406. doi: 10.1371 /journal.ppat.1006406

Marur, S., D’Souza, G., Westra, W. H., and Forastiere, A. A. (2010). HPV-associated head and neck cancer: a virus-related cancer epidemic. Lancet Oncol. 11, 781-789. doi: 10.1016/S1470-2045(10)70017-6

McBride, A. A. (2013). The papillomavirus E2 proteins. Virology 445, 57-79. doi: 10.1016/j.virol.2013.06.006

McGranahan, N., and Swanton, C. (2017). Clonal heterogeneity and tumor evolution: past, present, and the future. Cell 168, 613-628. doi: 10.1016/j.cell. 2017.01.018

McKinney, C. C., Hussmann, K. L., and McBride, A. A. (2015). The role of the DNA damage response throughout the papillomavirus life cycle. Viruses 7 , 2450-2469. doi: 10.3390/v7052450

McLaughlin-Drubin, M. E., Crum, C. P., and Münger, K. (2011). Human papillomavirus E7 oncoprotein induces KDM6A and KDM6B histone demethylase expression and causes epigenetic reprogramming. Proc. Natl. Acad. Sci. U.S.A. 108, 2130-2135. doi: 10.1073/pnas.1009933108

McMillan, N. A., Payne, E., Frazer, I. H., and Evander, M. (1999). Expression of the $\alpha 6$ integrin confers papillomavirus binding upon receptor-negative B-cells. Virology 261, 271-279. doi: 10.1006/viro.1999.9825

Merrick, D. T., Kittelson, J., Winterhalder, R., Kotantoulas, G., Ingeberg, S., Keith, R. L., et al. (2006). Analysis of c-ErbB1/epidermal growth factor receptor and c-ErbB2/HER-2 expression in bronchial dysplasia: evaluation of potential targets for chemoprevention of lung cancer. Clin. Cancer Res. 12, 2281-2288. doi: 10.1158/1078-0432.CCR-05-2291

Meyers, J. M., Uberoi, A., Grace, M., Lambert, P. F., and Munger, K. (2017). Cutaneous HPV8 and MmuPV1 E6 proteins target the NOTCH and TGF$\beta$ tumor suppressors to inhibit differentiation and sustain keratinocyte proliferation. PLoS Pathog. 13:e1006171. doi: 10.1371/journal.ppat.1006171

Middleton, K., Peh, W., Southern, S. A., Griffin, H., Sotlar, K., Nakahara, T., et al. (2003). Organization of the human papillomavirus productive cycle during neoplastic progression provides a basis for the selection of diagnostic markers. J. Virol. 77, 10186-10201. doi: 10.1128/JVI.77.19.10186-10201.2003

Modur, V., Joshi, P., Nie, D., Robbins, K. T., Khan, A. U., and Rao, K. (2016). CD24 expression may play a role as a predictive indicator and a modulator of cisplatin treatment response in head and neck squamous cellular carcinoma. PLoS One 11:e0156651. doi: 10.1371/journal.pone.0156651

Muñoz, N., Castellsagué, X., de González, A. B., and Gissmann, L. (2006). Chapter 1: HPV in the etiology of human cancer. Vaccine 24, S1-S10. doi: 10.1016/j. vaccine.2006.05.115

Nakashima, H., Honda, M., Inoue, H., Shibuta, K., Arinaga, S., Era, S., et al. (1995). Microsatellite instability in multiple gastric cancers. Int. J. Pathol. 64, 239-242. doi: $10.1002 /$ ijc. 2910640405
Napoletano, C., Bellati, F., Ruscito, I., Pernice, M., Zizzari, I. G., Caponnetto, S., et al. (2016). Immunological and clinical impact of cancer stem cells in vulvar cancer: role of CD133/CD24/ABCG2-expressing cells. Anticancer Res. 36, 5109-5116. doi: 10.21873/anticanres.11080

Noya, F., Chien, W. M., Broker, T. R., and Chow, L. T. (2001). p21cip1 degradation in differentiated keratinocytes is abrogated by costabilization with cyclin $\mathrm{E}$ induced by human papillomavirus E7. J. Virol. 75, 6121-6134. doi: 10.1128/JVI. 75.13.6121-6134.2001

Organista-Nava, J., Gómez-Gómez, Y., Ocadiz-Delgado, R., García-Villa, E., Bonilla-Delgado, J., and Lagunas-Martínez, A. (2016). The HPV16 E7 oncoprotein increases the expression of Oct3/4 and stemness-related genes and augments cell self-renewal. Virology 499, 230-242. doi: 10.1016/j.virol.2016.0 9.020

Ortiz, B. H., Ailawadi, M., Colitti, C., Muto, M. G., Deavers, M., Silva, E. G., et al. (2001). Second primary or recurrence? Comparative patterns of p53 and K-ras mutations suggest that serous borderline ovarian tumors and subsequent serous carcinomas are unrelated tumors. Cancer Res. 61, 7264-7267.

O’Shaughnessy, J. A., Kelloff, G. J., Gordon, G. B., Dannenberg, A. J., Hong, W. K., Fabian, C. J., et al. (2002). Treatment and prevention of intraepithelial neoplasia: an important target for accelerated new agent development. Clin. Cancer Res. 8, 314-346.

Patel, G. K., Yee, C. L., Terunuma, A., Telford, W. G., Voong, N., Yuspa, S. H., et al. (2012). Identification and characterization of tumor-initiating cells in human primary cutaneous squamous cell carcinoma. J. Invest. Dermatol. 132, 401-409. doi: 10.1038/jid.2011.317

Peh, W. L., Middleton, K., Christensen, N., Nicholls, P., Egawa, K., Sotlar, K., et al. (2002). Life cycle heterogeneity in animal models of human papillomavirusassociated disease. J. Virol. 76, 10401-10416. doi: 10.1128/JVI.76.20.1040110416.2002

Ponten, F., Berg, C., Ahmadian, A., Ren, Z. P., Nister, M., Lundeberg, J., et al. (1997). Molecular pathology in basal cell cancer with p53 as a genetic marker. Oncogene 15, 1059-1067. doi: 10.1038/sj.onc.1201435

Prevo, L. J., Sanchez, C. A., Galipeau, P. C., and Reid, B. J. (1999). p53-mutant clones and field effects in Barrett's esophagus. Cancer Res. 59, 4784-4787.

Prince, M. E., Sivanandan, R., Kaczorowski, A., Wolf, G. T., Kaplan, M. J., Dalerba, P., et al. (2007). Identification of a subpopulation of cells with cancer stem cell properties in head and neck squamous cell carcinoma. Proc. Natl. Acad. Sci. U.S.A. 104, 973-978. doi: 10.1073/pnas.0610117104

Pullos, A. N., Castilho, R. M., and Squarize, C. H. (2015). HPV infection of the head and neck region and its stem cells. J. Dent. Res. 94, 1532-1543. doi: $10.1177 / 0022034515605456$

Quint, K. D., Genders, R. E., de Koning, M. N., Borgogna, C., Gariglio, M., Bouwes Bavinck, J. N., et al. (2015). Human Beta-papillomavirus infection and keratinocyte carcinomas. J. Pathol. 235, 342-354. doi: 10.1002/path.4425

Ren, Z. P., Ponten, F., Nister, M., and Ponten, J. (1966). Two distinct p53 immunohistochemical patterns in human squamous skin cancer, precursors and normal epidermis. Int. J. Cancer 69, 174-179. doi: 10.1002/(SICI)10970215(19960621)69:3<174::AID-IJC4>3.0.CO;2-X

Rietbergen, M. M., Martens-de Kemp, S. R., Bloemena, E., Witte, B. I., Brink, A., Baatenburg de Jong, R. J., et al. (2014). Cancer stem cell enrichment marker CD98: a prognostic factor for survival in patients with human papillomaviruspositive oropharyngeal cancer. Eur. J. Cancer 50, 765-773. doi: 10.1016/j.ejca. 2013.11.010

Rodríguez, A. C., Schiffman, M., Herrero, R., Hildesheim, A., Bratti, C., Sherman, M. E., et al. (2010). Longitudinal study of human papillomavirus persistence and cervical intraepithelial neoplasia grade 2/3: critical role of duration of infection. J. Natl. Cancer Inst. 102, 315-324. doi: 10.1093/jnci/djq001

Rodríguez, A. C., Schiffman, M., Herrero, R., Wacholder, S., Hildesheim, A., Castle, P. E., et al. (2008). Rapid clearance of human papillomavirus and implications for clinical focus on persistent infections. J. Natl. Cancer Inst. 100, 513-517. doi: 10.1093/jnci/djn044

Rosenthal, A. N., Ryan, A., Hopster, D., and Jacobs, I. J. (2002). Molecular evidence of a common clonal origin and subsequent divergent clonal evolution in vulval intraepithelial neoplasia, vulval squamous cell carcinoma and lymph node metastases. Int. J. Cancer 99, 549-554. doi: 10.1002/ijc.10362

Ryser, M. D., Myers, E. R., and Durrett, R. (2015). HPV clearance and the neglected role of stochasticity. PLoS Comput. Biol. 11:e1004113. doi: 10.1371/journal.pcbi. 1004113 
Schelhaas, M., Shah, B., Holzer, M., Blattmann, P., Kühling, L., Day, P. M., et al. (2012). Entry of human papillomavirus type 16 by actin-dependent, clathrinand lipid raft-independent endocytosis. PLoS Pathog. 8:e1002657. doi: 10.1371/ journal.ppat.1002657

Schmitt, A., Rochat, A., Zeltner, R., Borenstein, L., Barrandon, Y., Wettstein, F. O., et al. (1996). The primary target cells of the high-risk cottontail rabbit papillomavirus colocalize with hair follicle stem cells. J. Virol. 70, 1912-1922.

Scholes, A. G., Woolgar, J. A., Boyle, M. A., Brown, J. S., Vaughan, E. D., Hart, C. A., et al. (1998). Synchronous oral carcinomas: independent or common clonal origin? Cancer Res. 58, 2003-2006.

Shafti-Keramat, S., Handisurya, A., Kriehuber, E., Meneguzzi, G., Slupetzky, K., and Kirnbauer, R. (2003). Different heparan sulfate proteoglycans serve as cellular receptors for human papillomaviruses. J. Virol. 77, 13125-13135. doi: 10.1128/JVI.77.24.13125-13135.2003

Shen, L., Kondo, Y., Rosner, G. L., Xiao, L., Hernandez, N. S., and Vilaythong, J. (2005). MGMT promoter methylation and field defect in sporadic colorectal cancer. J. Natl. Cancer Inst. 97, 1330-1338. doi: 10.1093/jnci/dji275

Sherman, L., Jackman, A., Itzhaki, H., Stoppler, M. C., Koval, D., and Schlegel, R. (1997). Inhibition of serum- and calcium-induced differentiation of human keratinocytes by HPV16 E6 oncoprotein: role of p53 inactivation. Virology 237, 296-306. doi: 10.1006/viro.1997.8778

Sheu, L. F., Chen, A., Tseng, H. H., Leu, F. J., Lin, J. K., Ho, K. C., et al. (1995). The assessment of p53 expression in nasopharyngeal carcinoma. Hum. Pathol. 26, 380-386. doi: 10.1016/0046-8177(95)90137-X

Shinmura, K., Tani, M., Isogaki, J., Wang, Y., Sugimara, H., and Yokota, J. (1998). RER phenotype and its associated mutations in familial gastric cancer. Carcinogenesis 19, 247-251. doi: 10.1093/carcin/19.2.247

Simon, R., Eltze, E., Schafer, K. L., Burger, H., Semjonow, A., and Hertle, L. (2001). Cytogenetic analysis of multifocal bladder cancer supports a monoclonal origin and intraepithelial spread of tumor cells. Cancer Res. 61, 355-362.

Slaughter, D. P., Southwick, H. W., and Smejkal, W. (1953). Field cancerization in oral stratified squamous epithelium; clinical implications of multicentric origin. Cancer 6, 963-968. doi: 10.1002/1097-0142(195309)6:5<963::AIDCNCR2820060515>3.0.CO;2-Q

Smeds, J., Warnberg, F., Norberg, T., Nordgren, H., Holmberg, L., and Bergh, J. (2005). Ductal carcinoma in situ of the breast with different histopathological grades and corresponding new breast tumour events: analysis of loss of heterozygosity. Acta Oncol. 44, 41-49. doi: 10.1080/02841860410002842

Spoden, G., Freitag, K., Husmann, M., Boller, K., Sapp, M., Lambert, C., et al. (2008). Clathrin- and caveolin-independent entry of human papillomavirus type 16-involvement of tetraspanin-enriched microdomains (TEMs). PLoS One 3:e3313. doi: 10.1371/journal.pone.0003313

Stubenrauch, F., Lim, H. B., and Laimins, L. A. (1998). Differential requirements for conserved E2 binding sites in the life cycle of oncogenic human papillomavirus type 31. J. Virol. 72, 1071-1077.

Sui, G., Zhou, S., Wang, J., Canto, M., Lee, E. E., and Eshleman, J. R. (2006). Mitochondrial DNA mutations in preneoplastic lesions of the gastrointestinal tract: a biomarker for the early detection of cancer. Mol. Cancer 5:73.

Syrjanen, K., Hakama, M., Saarikoski, S., Väyrynen, M., Yliskoski, M., Syrjänen, S., et al. (1990). Prevalence, incidence, and estimated life-time risk of cervical human papillomavirus infections in a nonselected Finnish female population. J. Sex. Transm. Dis. 17, 15-19. doi: 10.1097/00007435-199017010-00004

Tabor, M. P., Brakenhoff, R. H., Ruijter-Schippers, H. J., Kummer, J. A., Leemans, C. R., and Braakhuis, B. J. (2004). Genetically altered fields as origin of locally recurrent head and neck cancer: a retrospective study. Clin. Cancer Res. 10, 3607-3613. doi: 10.1158/1078-0432.CCR-03-0632
Tabor, M. P., Brakenhoff, R. H., Ruijter-Schippers, H. J., Van Der Wal, J. E., Snow, G. B., and Leemans, C. R. (2002). Multiple head and neck tumors frequently originate from a single preneoplastic lesion. Am. J. Pathol. 161, 1051-1060. doi: 10.1016/S0002-9440(10)64266-6

Tang, A. L., Owen, J. H., Hauff, S. J., Park, J. J., Papagerakis, S., Bradford, C. R., et al. (2013). Head and neck cancer stem cells: the effect of HPV-an in vitro and mouse study. Otolaryngol. Head Neck Surg. 149, 252-260. doi: 10.1177/ 0194599813486599

Tate, J. E., Mutter, G. L., Boynton, K. A., and Crum, C. P. (1997). Monoclonal origin of vulvar intraepithelial neoplasia and some vulvar hyperplasias. Am. J. Pathol. $150,315-322$.

Tomaić, V. (2016). Functional roles of E6 and E7 oncoproteins in HPVinduced malignancies at diverse anatomical sites. Cancers 8:E95. doi: 10.3390/ cancers 8100095

Tommasino, M. (2017). The biology of beta human papillomaviruses. Virus Res. 231, 128-138. doi: 10.1016/j.virusres.2016.11.013

Tyagi, A., Vishnoi, K., Mahata, S., Verma, G., Srivastava, Y., Masaldan, S., et al. (2016). Cervical cancer stem cells selectively overexpress HPV oncoprotein E6 that controls stemness and self-renewal through upregulation of HES1. Clin. Cancer Res. 22, 4170-4184. doi: 10.1158/1078-0432.CCR-15-2574

van Houten, V. M., Tabor, M. P., van den Brekel, M. W., Kummer, J. A., Denkers, F., Dijkstra, J., et al. (2002). Mutated P53 as molecular marker for the diagnosis of head and neck cancer. J. Pathol. 198, 476-486. doi: 10.1002/path.1242

Vishnoi, K., Mahata, S., Tyagi, A., Pandey, A., Verma, G., Jadli, M., et al. (2016). Cross-talk between human papillomavirus oncoproteins and hedgehog signaling synergistically promotes stemness in cervical cancer cells. Sci. Rep. 28:34377. doi: 10.1038/srep34377

Vlashi, E., Chen, A. M., Boyrie, S., Yu, G., Nguyen, A., Brower, P. A., et al. (2016). Radiation-induced dedifferentiation of head and neck cancer cells into cancer stem cells depends on human papillomavirus status. Int. J. Radiat. Oncol. Biol. Phys. 94, 1198-1206. doi: 10.1016/j.ijrobp.2016.01.005

Vokes, E. E., Agrawal, N., and Seiwert, T. Y. (2015). HPV-associated head and neck cancer. J. Natl. Cancer Inst. 107:djv344. doi: 10.1093/jnci/djv344

Wallace, N. A., Robinson, K., Howie, H. L., and Galloway, D. A. (2012). HPV 5 and 8 E6 abrogate ATR activity resulting in increased persistence of UVB induced DNA damage. PLoS Pathog. 8:e1002807. doi: 10.1371/journal.ppat.100 2807

Waridel, F., Estreicher, A., Bron, L., Flaman, J. M., Fontolliet, C., Monnier, P., et al. (1997). Field cancerisation and polyclonal p53 mutation in the upper aerodigestive tract. Oncogene 14, 163-169. doi: 10.1038/sj.onc.1200812

Xi, R., Pan, S., Chen, X., Hui, B., Zhang, L., Fu, S., et al. (2016). HPV16 E6E7 induces cancer stem-like cells phenotypes in esophageal squamous cell carcinoma through the activation of PI3K/Akt signaling pathway in vitro and in vivo. Oncotarget 7, 57050-57065. doi: 10.18632/oncotarget.10959

Conflict of Interest Statement: The authors declare that the research was conducted in the absence of any commercial or financial relationships that could be construed as a potential conflict of interest.

Copyright (c) 2018 Olivero, Lanfredini, Borgogna, Gariglio and Patel. This is an open-access article distributed under the terms of the Creative Commons Attribution License (CC BY). The use, distribution or reproduction in other forums is permitted, provided the original author(s) and the copyright owner are credited and that the original publication in this journal is cited, in accordance with accepted academic practice. No use, distribution or reproduction is permitted which does not comply with these terms. 